\title{
A Novel Conformation-Dependent Monoclonal Antibody Specific to the Native Structure of $\beta$-Lactoglobulin and Its Application
}

\author{
W. L. Chen, ${ }^{*}$ W. T. Liu, ${ }^{*}$ M. C. Yang, ${ }^{*}$ M. T. Hwang, ${ }^{*}$ J. H. Tsao,† and S. J. T. Mao*1 \\ ${ }^{*}$ Research Institute of Biochemical Engineering, Department of Biological Science and Technology, \\ National Chiao Tung University, Hsinchu, Taiwan, Republic of China \\ †Yong Rong Dairy, Chyayi, Taiwan, Republic of China
}

\section{ABSTRACT}

Molten globules are thought to be general intermediates in protein folding and unfolding. $\beta$-lactoglobulin ( $\beta$-LG) is one of the major bovine whey proteins, constituting $\sim 10$ to $15 \%$ of total milk proteins. We have recently identified $\beta$-LG as a superior marker for evaluating thermally processed milk. Strand $\mathrm{D}$ of $\beta$-LG participates in irreversible thermal unfolding as probed by a monoclonal antibody $(\mathrm{mAb})$ specific to thermally denatured $\beta$-LG. In the present study, we used native $\beta$-LG as an immunogen to test the hypothesis that a specific $\mathrm{mAb}$ against the native $\beta$-LG could be established. As result, a mAb $(4 \mathrm{H} 11 \mathrm{E} 8)$ directed against the native structure of $\beta$-LG was made. The antibody did not recognize the heat-denatured form of $\beta$-LG, such as its dimer and aggregates. Immunoassay using this "native" mAb showed that the stability of $\beta$-LG was at temperatures $\leq 70^{\circ} \mathrm{C}$. $\beta$-Lactoglobulin began to deteriorate between 70 and $80^{\circ} \mathrm{C}$ over time. The denaturation was correlated with the transition temperature of $\beta$-LG. Further chemical modification of Cys (carboxymethylation) or positively charged residues (acetylation) of $\beta$-LG totally abolished its immunoreactivity, confirming the conformation-dependent nature of this mAb. Using competitive ELISA, the $4 \mathrm{H} 11 \mathrm{E} 8 \mathrm{mAb}$ could determine the native $\beta$-LG content in commercially processed milks. Concentrations of native $\beta$-LG varied significantly among the local brands tested. From a technological standpoint, the $\mathrm{mAb}$ prepared in this study is relevant to the design and operation of appropriate processes for thermal sanitation of milk and of other dairy products.

Key words: $\beta$-lactoglobulin structure, immunoassay, native monoclonal antibody, thermal denaturation

\section{INTRODUCTION}

Molten globules are thought to be general intermediates in protein folding and unfolding (Chang et al.,

Received August 17, 2005.

Accepted November 2, 2005

${ }^{1}$ Corresponding author: mao1010@ms7.hinet.net
2000; Yang et al., 2001; Croguennec et al., 2004; Chen et al., 2005; Song et al., 2005). $\alpha$-Lactalbumin and $\beta$ LG are 2 of the major protein moieties of bovine whey proteins; $\beta$-LG constitutes $50 \%$ of the whey or about 10 to $15 \%$ of total milk proteins (Braunschweig et al., 2000; de Jongh et al., 2001; Wang and Lucey, 2003; Chen et al., 2005). Both of them are the most investigated models for understanding the mechanisms involved in protein stability, folding, and unfolding upon heating.

$\beta$-Lactoglobulin consists of 162 AA residues with 1 free Cys and 2 disulfide linkages (Pérez and Calvo, 1995; Sava et al., 2005). According to 3-D crystallographic studies, $\beta$-LG is predominantly a $\beta$-sheet configuration containing 9 antiparallel $\beta$-strands from $\mathrm{A}$ to I (Qin et al., 1999; Forge et al., 2000). Topographically, strands A through D form one surface of the barrel (calyx), and strands $\mathrm{E}$ through $\mathrm{H}$ form the other. The only $\alpha$-helical structure with 3 turns is at the $\mathrm{COOH}$ terminus, which follows strand $\mathrm{H}$ lying on the outer surface of the calyx (Uhrinova et al., 2000). A remarkable property of the calyx is its ability to bind in vitro hydrophobic molecules such as retinoids, fatty acids, vitamin D, and cholesterol (Qin et al., 1998; Wu et al., 1999; Kontopidis et al., 2002). We have recently identified that strand $\mathrm{D}$ of $\beta$-LG participates in the irreversibly thermal unfolding (Song et al., 2005) of which a new antigenic epitope in $\beta$-LG is being exposed between AA residues 66 and 76 when heating to $>70^{\circ} \mathrm{C}$ (Chen et al., 2005; Song et al., 2005). The unique structural and conformational changes made $\beta$-LG a superior marker for evaluating thermal processed milk (Chen et al., 2005).

In the present study, a conformation-dependent $\mathrm{mAb}$ (4H11E8) directed against native $\beta$-LG was prepared. The decreased immunoreactivity of $\beta$-LG as recognized by this "native" mAb was correlated to the thermal denaturation and conversion of $\beta$-sheet to the disordered structure of $\beta$-LG. Chemical modification of Cys and positively charged residues totally abolished the immunoreactivity of $\beta$-LG, confirming the nature of conformational dependency of this $\mathrm{mAb}$. Using competitive ELISA, the mAb was able to determine the native $\beta$ LG content in commercially processed milk. We showed 
that the native $\beta$-LG concentrations varied significantly among the brands. The utility of this native $\mathrm{mAb}$ in monitoring the quality of dairy products and the biological consequences is discussed in detail.

\section{MATERIALS AND METHODS}

\section{Preparation of Milk Samples and $\beta-L G$}

Fresh, bulked, whole raw milk obtained from a local dairy farm (Chyayi, Taiwan) was used for PAGE, Western blot, and ELISA analyses. For the heating experiments, each milk sample was heated at each temperature for the indicated time and immediately cooled down in an ice bath before the study. $\beta$-Lactoglobulin was purified from freshly skimmed milk using $40 \%$ saturated ammonium-sulfate top fraction followed by a $\beta$ LG antibody affinity column chromatography (Chen et al., 2004, 2005).

\section{Animal Care and Use}

Balb/c mice were purchased from the National Animal Center of the National Science Council of Taiwan. The mice were maintained and fed in light-cycled animal rooms; facilities and management were according to guidelines established and approved by the National Science Council.

\section{Immunization of Mice}

Female Balb/c mice, aged 5 to $7 \mathrm{wk}$, were used for immunization according to the method described previously (Yang and Mao, 1999; Chen et al., 2004, 2005). In brief, native $\beta$-LG [200 $\mu \mathrm{g}$ in $200 \mu \mathrm{L}$ of PBS containing $0.02 M$ phosphate and $0.12 M \mathrm{NaCl}$ (pH 7.4)] was homogenized with an equal volume of complete Freund's adjuvant by a 3-way stopcock for the first injection. The other 2 injections were then followed using incomplete Freund's adjuvant at $\mathrm{d} 7$ and 14 . Seven days following a final booster, plasma was obtained from blood collected in $0.1 \%$ EDTA (wt/vol) and was then used as a source for conventional $\beta$-LG polyclonal antibody. The titers of this antiserum were typically $>1: 10,000$ as judged by an ELISA (Chen et al., 2004). The spleen obtained was used for preparing hybridoma fusion.

\section{Production of $\mathrm{mAb}$}

Monoclonal antibodies were produced according to the standard procedures previously described (Mao et al., 1982, 1988, 1990; Chen et al., 2004). In brief, a myeloma cell line (FO) was fused with spleen cells from immunized mice at a ratio of 1:5. Fusion was carried out within $2 \mathrm{~min}$ at $37^{\circ} \mathrm{C}$ using $1 \mathrm{~mL}$ of $50 \%$ (wt/vol) polyethylene glycol containing $10 \%$ (vol/vol) DMSO (Hybri-Max, Sigma Chemical Co., St. Louis, MO). The cell mixture was then washed and resuspended in a hypoxanthine-aminopterin-thymidine medium (Hybri-Max) containing approximately $1 \times 10^{4} \mathrm{FO}$ cells $/ 100 \mu \mathrm{L}$. The suspended cells were distributed at $100 \mu \mathrm{L}$ per well in 96-well microtiter plates and incubated at $37^{\circ} \mathrm{C}$ in a $5 \% \mathrm{CO}_{2}$ incubator followed by the addition of $100 \mu \mathrm{L}$ of fresh hypoxanthine-aminopterin-thymidine medium after $7 \mathrm{~d}$. Subsequently, culture medium was assayed for the production of specific mAb, between 14 and 21 d following fusion, using a solid-phase ELISA as described subsequently.

\section{Screening of mAb Specific for Native $\beta$-LG Using ELISA}

About $0.5 \mu \mathrm{g}$ of raw or dry milk protein in $50 \mu \mathrm{L}$ of PBS was coated onto a microtiter plate (Nunc, Roskilde, Denmark). Unbound $\beta$-LG was washed and subsequently blocked by the addition of $350 \mu \mathrm{L}$ of $1 \%$ gelatin (wt/vol) for 30 min (Mao et al., 1983, 1988; Patton et al., 1983; Chen et al., 2004, 2005; Song et al., 2005). Following washes with PBS, $50 \mu \mathrm{L}$ of hybridoma culture medium (2 to $3 \mathrm{wk}$ following the fusion) was added and incubated at room temperature for 60 to $90 \mathrm{~min}$. Each well was then washed $3 \times$ with gelatin-PBS containing $0.1 \%$ gelatin and $0.05 \%$ Tween- 20 . Bound $\beta$-LG antibodies were detected using a goat antimouse IgG conjugated with horseradish peroxidase in gelatin-PBS for $30 \mathrm{~min}$. Finally, each well was washed and developed with $0.04 \%$ (wt/vol) 2,2-Azino-bis(3-ethylbenz-thiazoline-6-sulfonic acid) (ABTS) in PBS containing $0.01 \% \mathrm{H}_{2} \mathrm{O}_{2}$ (vol/vol). For primary screening, mAb that differentially reacted with native $\beta$-LG were selected, and those that reacted equally with native and thermally denatured $\beta$-LG were ignored. The selected hybridomas were expanded and subcloned by limiting dilutions for at least $2 \times$ to establish the monoclonals (Mao et al., 1988, 1990). The specificity of the mAb that recognized the native structure of $\beta$-LG was further confirmed by Western blot using native and heated $\beta$-LG $\left(95^{\circ} \mathrm{C}\right.$ for $\left.5 \mathrm{~min}\right)$.

\section{Gel Electrophoresis}

Sodium dodecyl sulfate-PAGE or native PAGE containing $15 \%$ (wt/vol) polyacrylamide (unless specified) was used for the characterization of the milk proteins via a modified procedure (Yang and Mao, 1999; Chen et al., 2005) similar to that described previously (Oldfield et al., 1998; Chen et al., 2005). All samples (5 to $20 \mu \mathrm{g}$ ) for SDS-PAGE were equilibrated in $10 \mathrm{~m} M$ Tris- 
$\mathrm{HCl}$ and $0.1 \%$ SDS (pH 7.6) before loading to the gel. A preheat treatment used in the conventional SDSPAGE was omitted in this study to ensure the native structure of unheated $\beta$-LG or milk proteins. The same procedures were conducted for native PAGE.

\section{Western Blot Analysis}

Following the SDS-PAGE or native PAGE, the gel was soaked instantly and briefly in a transfer buffer containing $25 \mathrm{~m} M$ Tris- $\mathrm{HCl}, 192 \mathrm{~m} M$ glycine, $20 \%$ methanol, and $0.0375 \%$ SDS (pH 8.3) for $30 \mathrm{~s}$ (Chen et al., 2004, 2005). The gel was then immediately electrotransferred to a nitrocellulose membrane (Hybond-ECL extra, Amersham, Buckingham, UK) at $90 \mathrm{~mA}$ for 45 min in a semidry transfer cell (BioRad, Hercules, CA). The membrane was immersed in $1 \%$ gelatin for $1 \mathrm{~h}$ with gentle shaking. Following 3 washes with PBS for $5 \mathrm{~min}$, the membrane was incubated with tested $\mathrm{mAb}$ (with appropriate dilution in PBS containing $0.1 \%$ gelatin and $0.05 \%$ Tween-20) for $1 \mathrm{~h}$ followed by 3 washes and incubation with horseradish peroxidase-conjugated goat antimouse IgG for $1 \mathrm{~h}$. Finally, the membrane was developed with $0.1 \mathrm{mg} / \mathrm{mL}$ of 3 -3'-diaminobenzidine (3, $3^{\prime}, 4,4^{\prime}$-tetra-amino-biphenyl) containing $0.01 \% \mathrm{H}_{2} \mathrm{O}_{2}$ in PBS.

\section{Trypsin and Cyanogen Bromide Fragmentation}

For trypsin treatment, $50 \mu \mathrm{g}$ of $\beta$-LG in $100 \mu \mathrm{L}$ of PBS was incubated with $1 \mu \mathrm{L}$ of trypsin $(0.1 \mathrm{mg} / \mathrm{mL})$ at room temperature for $4 \mathrm{~h}$ (Chen et al., 2004; Song et al., 2005). Trypsinized $\beta$-LG was analyzed on SDSPAGE (18\% polyacrylamide) followed by a Western blot. Cyanogen bromide (CNBr) fragmentation was conducted according to the method previously described with some modifications (Mao et al., 1977; Song et al., 2005). In general, $5 \mathrm{mg}$ of $\beta$-LG was first dissolved in $70 \%$ (vol/vol) trifluoroacetic acid as previously described (Caprioli et al., 1991; Andrews et al., 1992) with the addition of $10 \mathrm{mg}$ of $\mathrm{CNBr}$ in the dark for $24 \mathrm{~h}$ at room temperature. After $3 \times$ evaporation in a lyophilizer with the addition of $5 \times$ volume of deionized water, the dry material was dissolved in the $10 \mathrm{~m} M$ phosphate buffer ( $\mathrm{pH}$ 7.0). The immunoreactivity of CNBr fragments was then analyzed on an 18\% SDS-PAGE followed by a Western blot.

\section{Acetylation and Carboxymethylation of $\beta-L G$}

Chemical modification of $\beta$-LG by acetylation was conducted by a modification of the procedure previously described (Mao et al., 1980; Song et al., 2005). To $5 \mathrm{mg}$ of $\beta$-LG in $2 \mathrm{~mL}$ of $50 \mathrm{~m} M$ sodium bicarbonate $(\mathrm{pH}$
8.0) containing $6 M$ urea, $5 \mu \mathrm{L}$ of acetic anhydride was slowly added into the reaction mixture step by step while maintaining the $\mathrm{pH}$ at 8.0 using $0.1 \mathrm{M} \mathrm{NaOH}$. After $3 \mathrm{~h}$ of incubation at room temperature, the acetylated protein was desalted on a Biogel P-2 column eluted by $0.05 \mathrm{M}$ ammonium bicarbonate and lyophilized.

For carboxymethylation (Mao et al., 1980; Tseng et al., 2004; Song et al., 2005), $5 \mathrm{mg}$ of $\beta$-LG was first dissolved in $5 \mathrm{~mL}$ of $0.1 M$ Tris-HCl buffer ( $\mathrm{pH} 8.6$ ) containing $6 \mathrm{M}$ ultra-pure urea and $0.02 M$ 2-mercaptoethanol. Following flushing with nitrogen, $20 \mathrm{mg}$ of iodoacetic acid was added into the reaction mixture while maintaining the $\mathrm{pH}$ at 8.6 via the addition of $0.1 \mathrm{M} \mathrm{NaOH}$ and incubation for another $3 \mathrm{~h}$. Finally, carboxymethylated (CM) $\beta$-LG was desalted on a BioGel P2 column eluted by $0.05 M$ ammonium bicarbonate and lyophilized. According to AA analysis, the CM $\beta$ LG contained 4.9 residues of CM Cys $/ \mathrm{mol}$ of $\beta$-LG.

\section{Standard Displacement Curve of Milk Samples and Determination of $\beta$-LG Concentration}

In brief, $\beta$-LG $(0.5 \mu \mathrm{g}$ in $50 \mu \mathrm{L}$ of PBS) was first immobilized onto each microtiter well followed by washes and blocking as described for ELISA. After washes, $50 \mu \mathrm{L}$ of the milk samples (raw or commercially processed milks) at various dilutions in $0.1 \%$ gelatinPBS was mixed with $50 \mu \mathrm{L}$ of the $4 \mathrm{H} 11 \mathrm{E} 8 \mathrm{mAb}$ and incubated at room temperature for $1 \mathrm{~h}$. Following washes, a secondary antibody (goat antimouse IgG conjugated with horseradish peroxidase) was added, incubated, washed, and then developed with ABTS. To determine the native $\beta$-LG content of each milk sample, the $\beta$-LG concentration was based on the equivalent immunoreactivity extrapolated from that using purified $\beta$-LG as a standard. The mean value of each unknown sample was obtained from triplicated determinations with an intraassay variation of $<8 \%$.

\section{Milk Samples for Native PAGE}

Different brands of commercially processed milk were purchased from the local market, and one was from the US market (Kroger, Cincinnati, OH). Freshly bulked, whole raw milk was obtained from a local dairy farm. Samples were immediately centrifuged at $13,000 \mathrm{rpm}$ $(15,500 \times g)$ for $1 \mathrm{~h}$ at $4^{\circ} \mathrm{C}$. The top layer in the supernatant was carefully removed, and the remaining fraction (whey protein) containing minimal casein was used for the analysis of PAGE and Western blot.

\section{RESULTS}

Using dry milk as an immunogen, we have recently produced a mAb that can distinguish dry milk from raw 


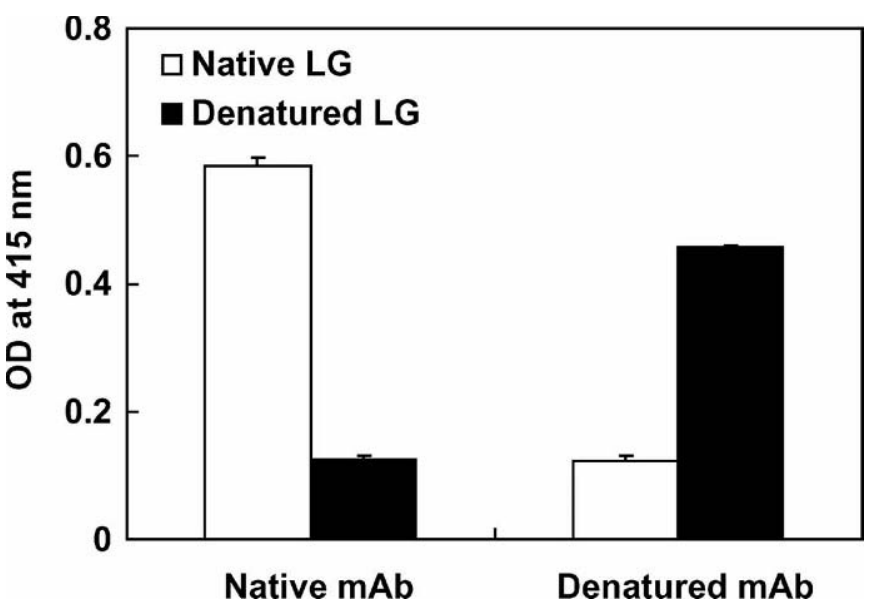

Figure 1. Typical example of a monoclonal antibody $(\mathrm{mAb})$ that differentially reacted with native and heated $\beta$-LG. Immunoreactivity was monitored using an ELISA, and an equal amount of native and heated $\beta$-LG protein $(1 \mu \mathrm{g})$ was coated onto the microtiter plate. $\beta$ Lactoglobulin was heated at $95^{\circ} \mathrm{C}$ for 5 min prior to the coating. Each bar represents the mean \pm SEM of triplicate determinations. OD = optical density.

milk (Chen et al., 2004). Antigenic mapping shows that the epitope is located between residues 66 and 76 in strand $\mathrm{D}$ of thermally denatured $\beta$-LG (Song et al., 2005). When heated to $>80^{\circ} \mathrm{C}$, the epitope region of $\beta$ $\mathrm{LG}$ is exposed and bound by the mAb (3E7G7). Therefore, the antibody is defined as "denatured" mAb. In the present study, we tested the hypothesis that a native $\beta$ LG mAb could be prepared when native $\beta$-LG was used for immunization. Approximately 500 hybridoma clones were screened, among which $1 \mathrm{mAb}$ was established $(4 \mathrm{H} 11 \mathrm{E} 8)$ that specifically reacted with the native $\beta$-LG, but not heat-denatured $\beta$-LG. A typical example is shown in Figure 1: mAb 4H11E8 bound primarily to native $\beta$-LG in contrast to denatured $\mathrm{mAb}$ that bound to heated $\beta$-LG.

\section{Western Blot Analysis}

Using SDS-PAGE and Western blot analysis, mAb $4 \mathrm{H} 11 \mathrm{E} 8$ only recognized the native monomeric $\beta$-LG of raw and dry milk, but not denatured $\beta$-LG dimer or polymers of dry milk (Figure 2). The denatured $\beta$-LG was almost nondetectable by Coomassie blue staining. Such minimal denatured forms, however, were observed using a denatured $\mathrm{mAb}$ prepared previously [Figure 2 (right panel); Chen et al., 2004, 2005]. To demonstrate the specificity and sensitivity of the $4 \mathrm{H} 11 \mathrm{E} 8 \mathrm{mAb}$, we heated raw milk at $95^{\circ} \mathrm{C}$ over time. Following a native PAGE and Western blot analysis, $\beta$-LG was found to be severely denatured after heating of milk at $95^{\circ} \mathrm{C}$ for $>2$ min (Figure $3 \mathrm{~A}$ ). Formation of large polymers from either self-associated $\beta$-LG or $\beta$ LG conjugates (with other milk proteins) was observed for denatured $\mathrm{mAb}$ (Figure 3B). Because more $\beta$-LG aggregates formed after heating for $>4 \mathrm{~min}$, less denatured $\beta$-LG could run into the gel; such that some of the sample became undetectable by the denatured $\mathrm{mAb}$ on the blot (Figure 3B). It was obvious that $\mathrm{mAb}$ $4 \mathrm{H} 11 \mathrm{E} 8$ only recognized the native $\beta$-LG. We herein define it as "native" mAb.

\section{Effect of Heat on the Immunoreactivity of Raw Milk}

Quantitative ELISA was then used to analyze immunoreactivity of native $\mathrm{mAb}$ against raw milk heated at different temperatures over time (Figure 4). The $\beta$-LG thermal denaturation curve shows that, in general, $\beta$ $\mathrm{LG}$ was stable at the temperatures $\leq 70^{\circ} \mathrm{C}$. It began to deteriorate between 70 and $80^{\circ} \mathrm{C}$. Most interestingly, the thermal denaturation curve determined by the immunoassay in this study is almost identical to that determined by the structural change of $\beta$-LG using a physical-chemical approach: a circular dichroic spectrum (Chen et al., 2005). A severe decrease in immunoreactivity was observed when heating was $>80^{\circ} \mathrm{C}$. This finding demonstrated that the structural loss of native $\beta$-LG could be probed by the native $4 \mathrm{H} 11 \mathrm{E} 8 \mathrm{mAb}$.

\section{Effect of Conformational Change on the Immunoreactivity of $\beta-L G$}

We anticipated that the overall structure of $\beta$-LG might determine the specific nature of this native $\mathrm{mAb}$. To test this hypothesis, we chemically modified $\beta$-LG by carboxymethylation to break up the disulfide linkage in altering its overall structure. As shown in Figure 5A, the native $\mathrm{mAb}$ reacted with native $\beta$-LG, but not that CM using a Western blot analysis. Notably, an extra band was present in the modified $\beta$-LG (Coomassie blue staining), which might have been generated during the modification by an unknown mechanism. Additional acetylation on the lysyl residues, limited trypsin treatment, and $\mathrm{CNBr}$ fragmentation also diminished the immunoreactivity (Figure 5, B through D). It should be noted here that both of these 2 chemical modifications were carried out in the presence of $6 M$ urea. The modified $\beta$-LG was dialyzed against PBS prior to the Western blot to remove the urea. After dialysis, the immunoreactivity of $\beta$-LG treated with $6 M$ urea was retained because of the renaturation of the conformation. Also, sample treated with trifluoroacetic acid alone (without the presence of cleavage reagent $\mathrm{CNBr}$ ) did not show the loss of immunoreactivity after removing the trifluoroacetic acid by lyophilization. However, $\beta$-LG treated with $8 M$ urea without dialysis resulted in a complete 
SDS-PAGE

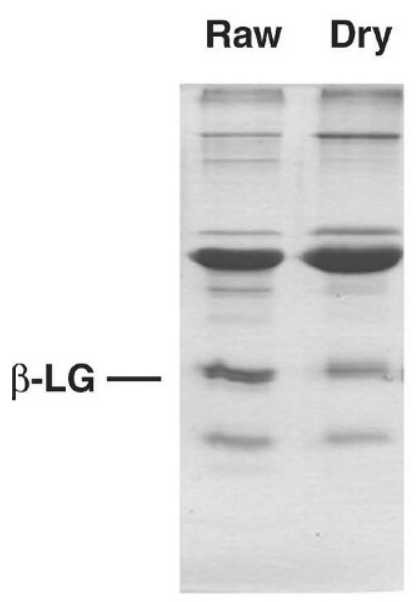

Western Blot

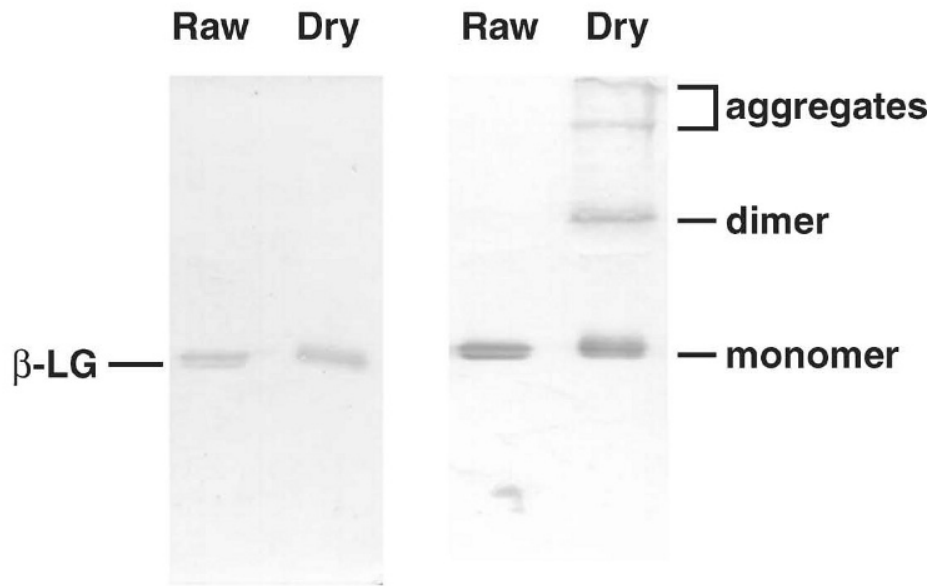

\section{Native mAb Denatured mAb}

Figure 2. Characterization of native monoclonal antibody (mAb) 4H11E8 using Western blot. Left: raw and dry milk on a 15\% SDSPAGE followed by Coomassie blue staining. Right: raw and dry milk on SDS-PAGE followed by Western blot using native and denatured $\mathrm{mAb}$. The data show that native $\mathrm{mAb}$ only recognizes the native form of $\beta$-LG, but not $\beta$-LG dimer, polymers, or aggregates. The denatured forms of $\beta$-LG cannot be seen by Coomassie staining.

loss of the immunoreactivity on a nitrocellulose using a dot-blot assay (data not shown). Taken together, these results suggest that the native mAb was not sequentially dependent.

\section{Determination of Native $\beta$-LG in Processed Milk from the Local Market}

Using competitive ELISA by native mAb, we monitored the immunoreactivity of native $\beta$-LG in processed milk. A typical example for the standard displacement curves resulting from the samples purchased from the local market is shown in Figure 6. Optical density is inversely correlated with the expression of native $\beta$-LG in tested milks. The raw milk shows a superior $\beta$-LG immunoreactivity to most of the brands tested (Figure 6 ) and was almost superimposed with one brand that was claimed to be pasteurized at $<65^{\circ} \mathrm{C}$ for $30 \mathrm{~min}$ (low temperature; long pasturization). Using a standard curve of native $\beta$-LG (data not shown), the extrapolated $\beta$-LG content for each brand is listed in Table 1 . The $\beta$-LG left over in each processed brand varied significantly. Interestingly, the native $\beta$-LG values in a US brand (No. 3) and domestic brand (No. 2; low temperature and long pasteurization) were essentially identical to those in raw milk. Finally, we characterized the native $\beta$-LG content in processed milk using a native PAGE. $\beta$-Lactoglobulin was found severely denatured in some of the brands (Figure 7) and was almost consis- tent with the quantitative ELISA using native mAb (Table 1).

\section{DISCUSSION}

It is well established that the heating process during the preparation of dry milk causes structural changes in some milk proteins (Needs et al., 2000; Chen et al., 2004). Although such changes are subtle, we have demonstrated that the denatured $\mathrm{mAb}$ can distinguish minor differences between the dry and raw milks (Chen et al., 2004). Subsequently, $\beta$-LG was found to be the component responsible for the specificity of that denatured mAb (Chen et al., 2004). Following antigenic mapping using synthetic peptides, we have recently delineated the epitope to be located between residues 66 and 76 of the denatured D strain of $\beta$-LG (Song et al., 2005). Thus, this suggests that $\beta$-LG is a sensitive thermal marker that can be probed by a mAb specific to denatured $\beta$-LG. Conversely, it predicts that a mAb specific to native $\beta$-LG can be made following appropriate immunization and screening. For this reason, in the present study, we used native $\beta$-LG as an immunogen to test the hypothesis that a specific mAb against the native structure of $\beta$-LG could be established.

Because those monoclonals that cross-reacted with denatured $\beta$-LG had already been eliminated in the initial screening, the remaining clones that were specific to native $\beta$-LG should be most likely directed 


\section{A. Native mAb}

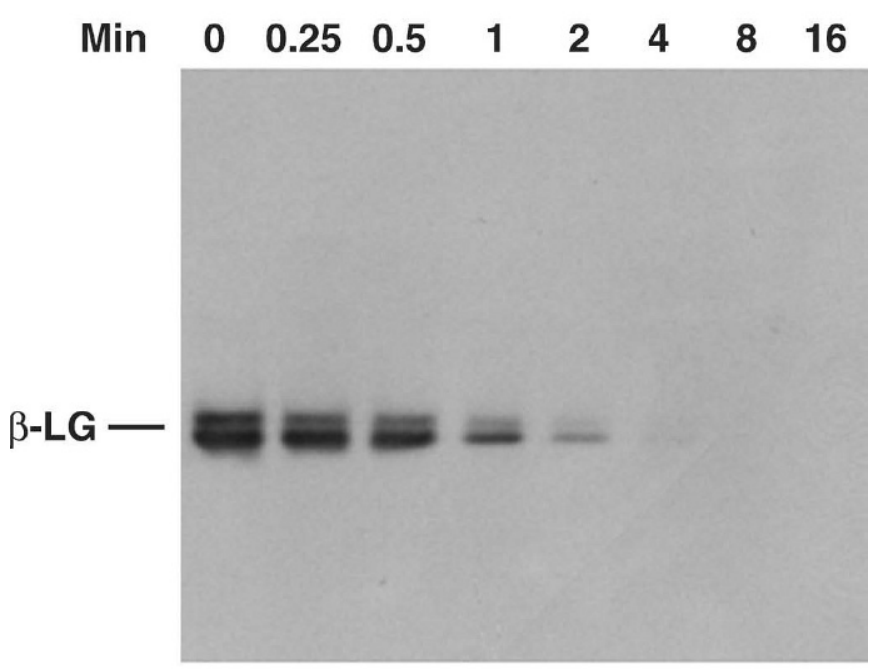

\section{B. Denatured mAb}

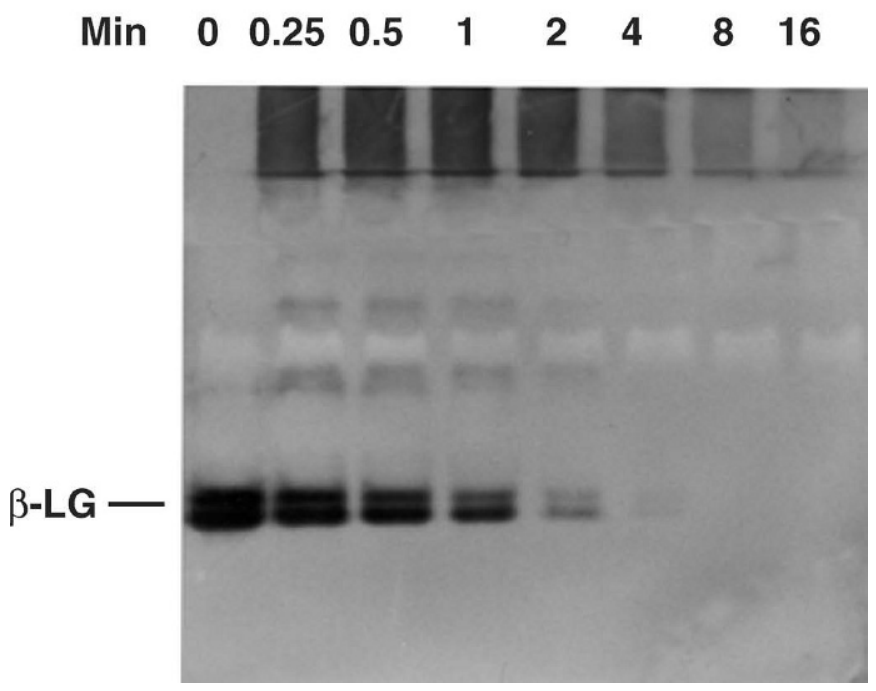

Figure 3. Thermal denaturation of $\beta$-LG characterized by native monoclonal antibody $(\mathrm{mAb}) 4 \mathrm{H} 11 \mathrm{E} 8$ and denatured $\mathrm{mAb}$ on native PAGE. The experiment was carried out by heating raw milk at $95^{\circ} \mathrm{C}$ over time (0 to $16 \mathrm{~min}$ ) followed by a Western blot using $\mathrm{mAb}(\mathrm{A})$ and denatured $\mathrm{mAb}(\mathrm{B})$. Two isoforms of $\beta$-LG were seen on native PAGE. The native $\mathrm{mAb}$ does not recognize the thermally denatured $\beta$-LG.

against a conformational dependent epitope. Several lines of evidence support this possibility. First, from the known 3-D structure, Cys residues are responsible for stabilizing the overall structure of $\beta$-LG by crosslinking the positions strand D Cys-66 and carboxyl terminus Cys-160 (Creamer et al., 2004; Song et al., 2005).

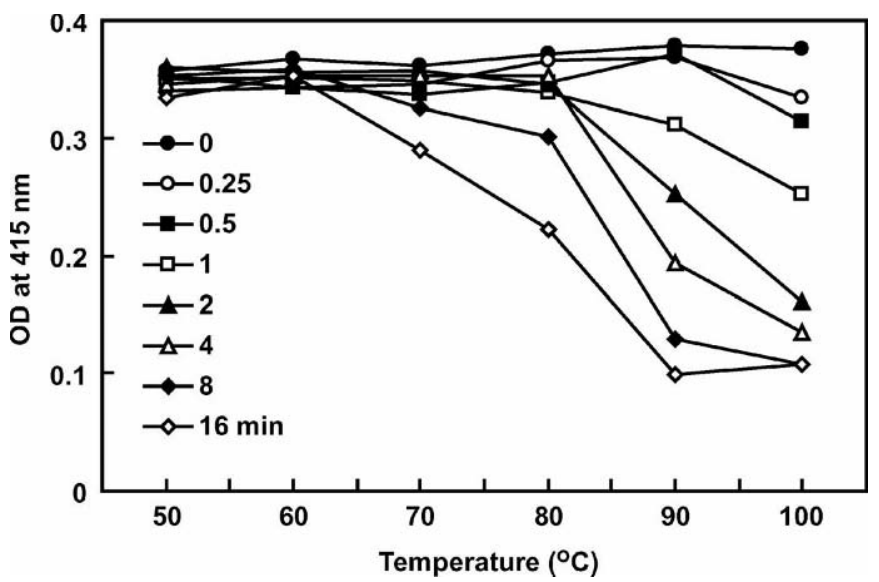

Figure 4. Immunoreactivity of $\beta$-LG in raw milk heated at different temperatures over time. Each milk sample was independently heated at each respective temperature with the time as indicated and immediately cooled in an ice bath before immobilizing onto the ELISA plate. Immunoreactivity was monitored by an ELISA using native $\mathrm{mAb} 4 \mathrm{H} 11 \mathrm{E} 8$. Each point represents a mean of duplicated determinations. The decrease in immunoreactivity assessed by native $\mathrm{mAb}$ is essentially correlated to the molten globule state of $\beta$-LG with a transition between 70 and $80^{\circ} \mathrm{C} . \mathrm{OD}=$ optical density.

Our chemical modification (carboxymethylation) on Cys residues not only resulted in the conformational change of $\beta$-LG as shown in our previous study (Song et al., 2005.), but also completely abolished the immunoreactivity in the present study (Figure 4). Second, acetylation. which neutralizes the positively charged lysyl residues (at $\mathrm{pH} 10$ ), resulted in a total loss of the immunoreactivity of $\beta$-LG (Figure 5B). These charged residues are also crucial in maintaining the overall 3-D structure of a given protein or $\beta$-LG (Song et al., 2005). Third, in contrast to the denatured $\beta$-LG mAb (Chen et al., 2004; Song et al., 2005), this native $\mathrm{mAb}$ did not recognize the $\mathrm{CNBr}$ fragment (Figure 4). It is conceivable that this $\mathrm{mAb}$ may not be sequence dependent. It was tempting to speculate that the entire $\beta$-LG molecule was required in maintaining the antigenic structure, but we could not rule out that such fragmentation might directly cleave the epitope, resulting in a loss of immunoreactivity. We then denatured the $\beta$-LG using $8 M$ urea and demonstrated that it was not immunoreactive using a dot-blot assay (data not shown). Thus, it further supports the notion that conformation of $\beta$-LG plays a role in this native $\mathrm{mAb}$. With respect to $\mathrm{CNBr}$ cleavage, we used $70 \%$ trifluoroacetic acid instead of formic acid. Although formic acid is commonly used because of its good solubility and denaturation for a given protein, it may damage Trp and Tyr residues (Morrison et al., 1990). It may also result in formylation and so increase peptide mass (Beavis and Chait, 1990). Conversely, trifluoroacetic acid is preferable to formic acid, giving a 
A. Carboxymethylation

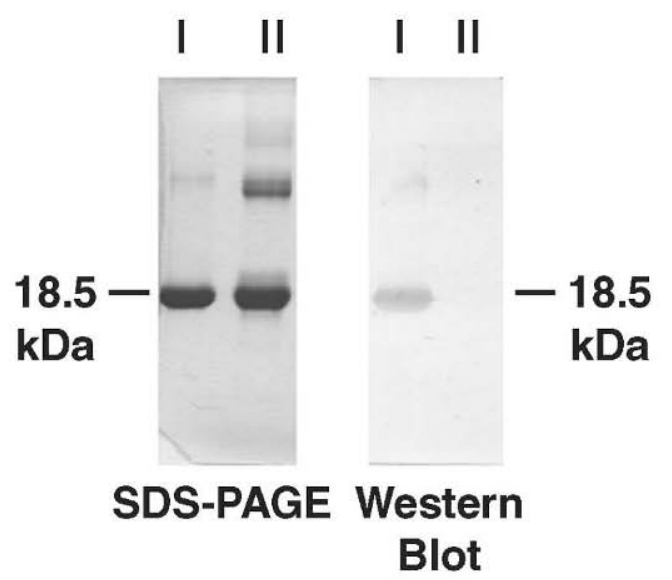

C. Trypsin treatment

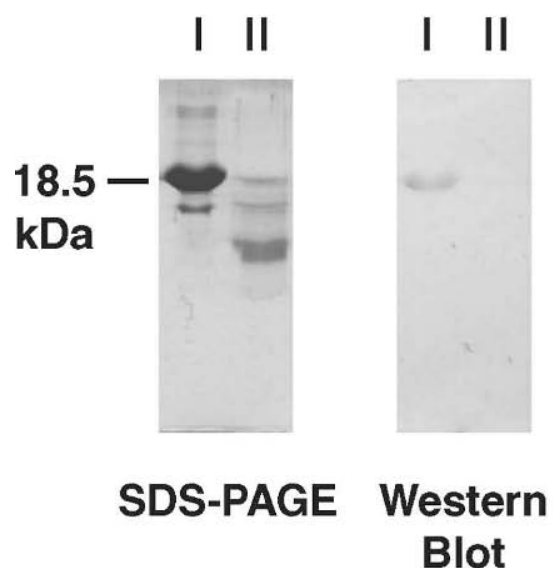

B. Acetylation

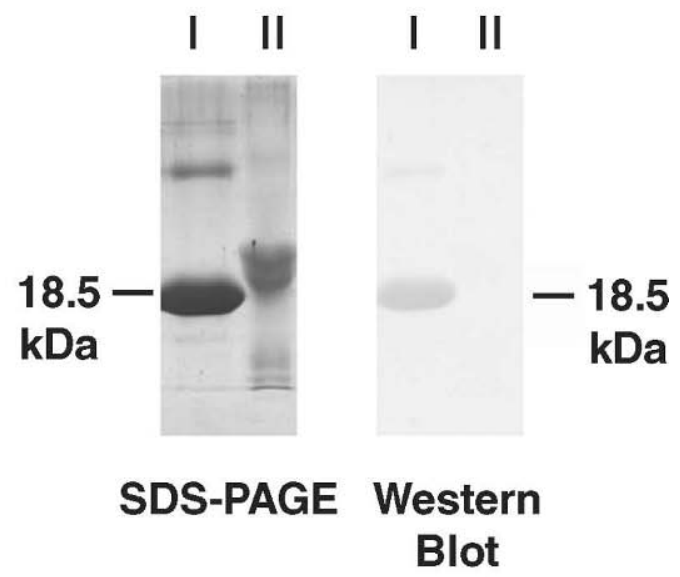

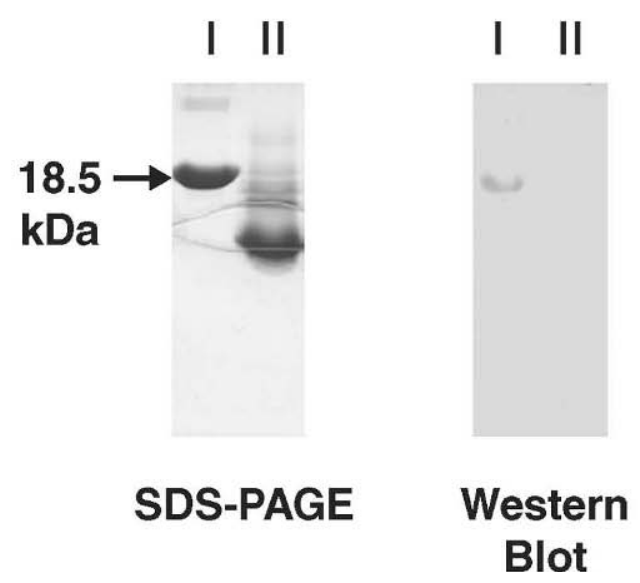

Figure 5. Role of disulfide linkage in maintaining the antigenic structure of $\beta$-LG and the effect of chemical modifications on its immunoreactivity. A) $\beta$-LG was irreversibly reduced by carboxymethylation; lane I: native $\beta$-LG and lane II: carboxymethylated $\beta$-LG. B) $\beta$-LG was modified before (lane I) and after (lane II) acetylation at pH 10. C) $\beta$-LG was treated before (lane I) and after (lane II) trypsin cleavage. D) $\beta$-LG was treated before (lane I) and after (lane II) cyanogen bromide (CNBr) cleavage. The left side of each panel represents the analysis of $20 \%$ SDS-PAGE using Coomassie blue staining, except for Panel A, where staining was at 15\% SDS-PAGE. The right side of each panel represent the Western blot analysis using native monoclonal antibody $4 \mathrm{H} 11 \mathrm{E} 8$. The data suggest that the immunoreactivity is dependent on the overall structure of $\beta$-LG (A and $\mathrm{B}$ ), and the epitope is likely not located in the $\beta$-LG fragments $(\mathrm{C}$ and $\mathrm{D})$.

satisfactory result (Caprioli et al., 1991; Andrews et al., 1992), but the reaction time is somewhat slower than that of formic acid.

Taken together, our study reveals that this native $\mathrm{mAb}$ is conformationally dependent on the overall structure of $\beta$-LG. It is difficult for us to map out the specific antigenic determinant at the present time, but it is very possible that Cys-121 or its neighboring resi- dues might play an essential role in the recognition of the native $\mathrm{mAb}$. Because the free Cys-121 residue is known to be involved in the simplest form of covalently linked $\beta$-LG dimer upon heating (Panick et al., 1999; Farrell et al., 2004; Kontopidis et al., 2004), such dimerization causes the loss of our mAb binding (Figure 2). The covalent linkage may eventually block the 4H11E 8 binding via steric hindrance (Figure 2). Furthermore, 


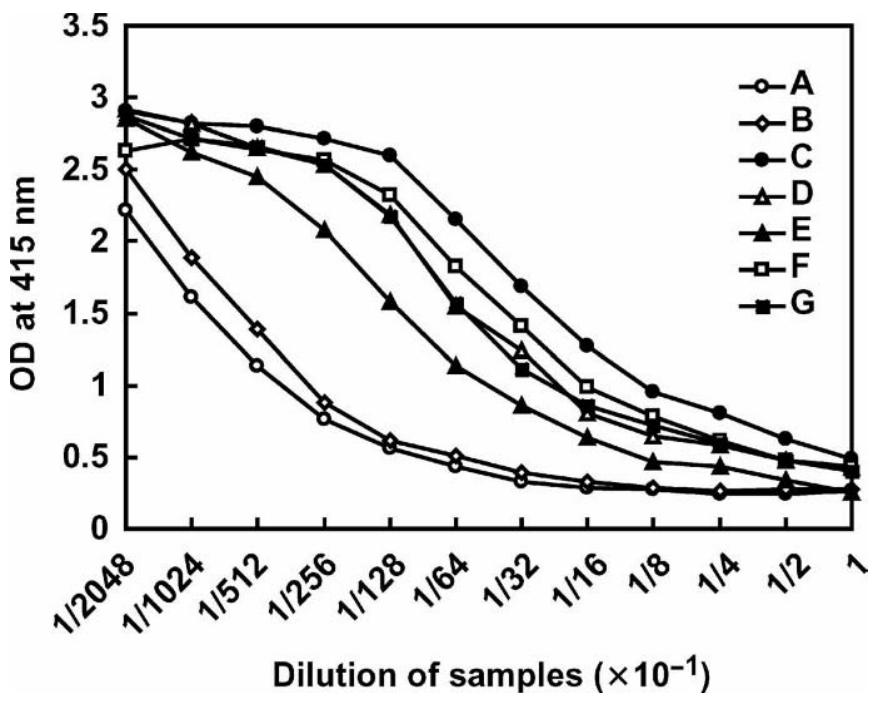

Figure 6. Typical example of immunoreactivity of native $\beta$-LG in raw and processed milk as determined by a competitive ELISA. Native $\beta$-LG was used as an immobilized antigen while competing the binding of raw and processed milks for native monoclonal antibody 4H11E8. A) raw milk, B) processed milk from a local market pasteurized at $60^{\circ} \mathrm{C}$ for $30 \mathrm{~min}$, and $\mathrm{C}$ through G) processed milks purchased from the local market with undisclosed heating procedures. Apparently, the immunoreactivity of $\beta$-LG in most of the processed milk was attenuated as compared with the raw milk. $\mathrm{OD}=$ optical density.

the Cys-121 is also responsible for cross linking with $\beta$ LG aggregates or with other milk proteins upon heating (Chen et al., 2004; Creamer et al., 2004; Croguennec et al., 2004; Chen et al., 2005). We have attempted to map out the antigenic structure for this native mAb using

Table 1. Determination of native $\beta$-LG from commercially processed milk

\begin{tabular}{ll}
\hline $\begin{array}{l}\text { Processed milk } \\
\text { from market }^{1}\end{array}$ & $\begin{array}{l}\text { Amount of native } \\
\beta \text {-LG }(\mathrm{mg} / \mathrm{mL})^{2}\end{array}$ \\
\hline 1 & $5.50 \pm 0.06$ \\
2 & $5.35 \pm 0.15$ \\
3 & $5.40 \pm 0.12$ \\
4 & $2.98 \pm 0.27$ \\
5 & $0.60 \pm 0.08$ \\
6 & $0.36 \pm 0.02$ \\
7 & $0.55 \pm 0.08$ \\
8 & $1.84 \pm 0.36$ \\
9 & $0.39 \pm 0.03$ \\
10 & $0.34 \pm 0.08$ \\
12 & $0.68 \pm 0.18$ \\
13 & $1.05 \pm 0.16$ \\
14 & $0.49 \pm 0.04$ \\
\hline
\end{tabular}

${ }^{1}$ Samples 1, 2, and 3 represent a raw milk and a processed milk of a local market pasteurized at $60^{\circ} \mathrm{C}$ for $30 \mathrm{~min}$ and a processed milk of a U.S. market pasteurized with a standard procedure, respectively. Samples 4 through 13 represent various processed milks of a local market with an undisclosed heating procedure.

${ }^{2}$ Determination of $\beta$-LG was by competitive ELISA. Each value represents the mean \pm SEM of triplicate determinations. the peptide array technique previously established in our laboratory (Song et al., 2005), but we failed to show any immunoreactivity against the synthetic peptides. Therefore, we can only speculate that Cys-121 (or its neighboring residues) is essential for $\mathrm{mAb}$ recognition, but the antigen-antibody interaction may still need the integrity of the native structure of $\beta$-LG. Final conclusive interpretation of the involvement of Cys-121 with respect to the native $\mathrm{mAb}$ recognition probably lies in the use of recombinant $\beta$-LG with a single mutation on Cys-121. This experiment is now in progress in our laboratory using site-directed mutagenesis. In addition, the acetylation experiment conducted in this study (Figure 5) tended to suggest the possible involvement of lysyl residues in the antigenic determinant similar to that found previously (Song et al., 2005), in which the positively charged residues are frequently expressed on a surface epitope.

As to the biological function of $\beta$-LG, studies have shown that it produces hypocholesterolemic (Nagaoka et al., 2001) and antioxidant effects (Peña-Ramos and Xiong, 2001; Wong and Kitts, 2003; HernandezLedesma et al., 2005) and may also serve as a growth factor for mammalian cells (Feuermann et al., 2004). It can transport and complex with retinol and fatty acids via its hydrophobic binding pocket calyx of $\beta$-LG (Song et al., 2005). Interestingly, $\beta$-LG is not only acid resistant in gastrointestinal tracts, but it also possesses a superior absorption capability via a receptor-mediated process (Dew and Ong, 1997). Our recent study demonstrates the loss of this binding capability when $\beta$-LG is denatured by heating to $>80^{\circ} \mathrm{C}$. We have further suggested that it is the exposure of hydrophobic region (residues 66 to 76) of the D strand to a polar environment that destabilizes the calyx structure and complex formation with retinol and palmitic acid (Song et al., $2005)$. Because $\beta$-LG is also labile to heat treatment by forming large polymers with other milk proteins (Chen et al., 2004, 2005), it is tempting to speculate that heat may reduce the extent of absorption of $\beta$-LG through the gut. Conceivably, additional overheating should be avoided to maintain the physiologic role of $\beta$-LG. Our $\mathrm{mAb}$ may provide a novel mean for monitoring the native structure of $\beta$-LG in heat-processed milks. It is of interest to note that the reported transition temperature of native $\beta$-LG (between 70 and $80^{\circ} \mathrm{C}$ ) is almost completely agreeable with the decrease in immunoreactivity for the native mAb (Figure 4). From a technological standpoint, this mAb may be relevant to the design and operation of appropriate processes for thermal sanitation of milk and other dairy products. For example, using a standard Ohio State University method of manufacturing whey protein curd, milk is short-time pasteurized (about $72^{\circ} \mathrm{C}$ for $30 \mathrm{~s}$ ) and held overnight at 


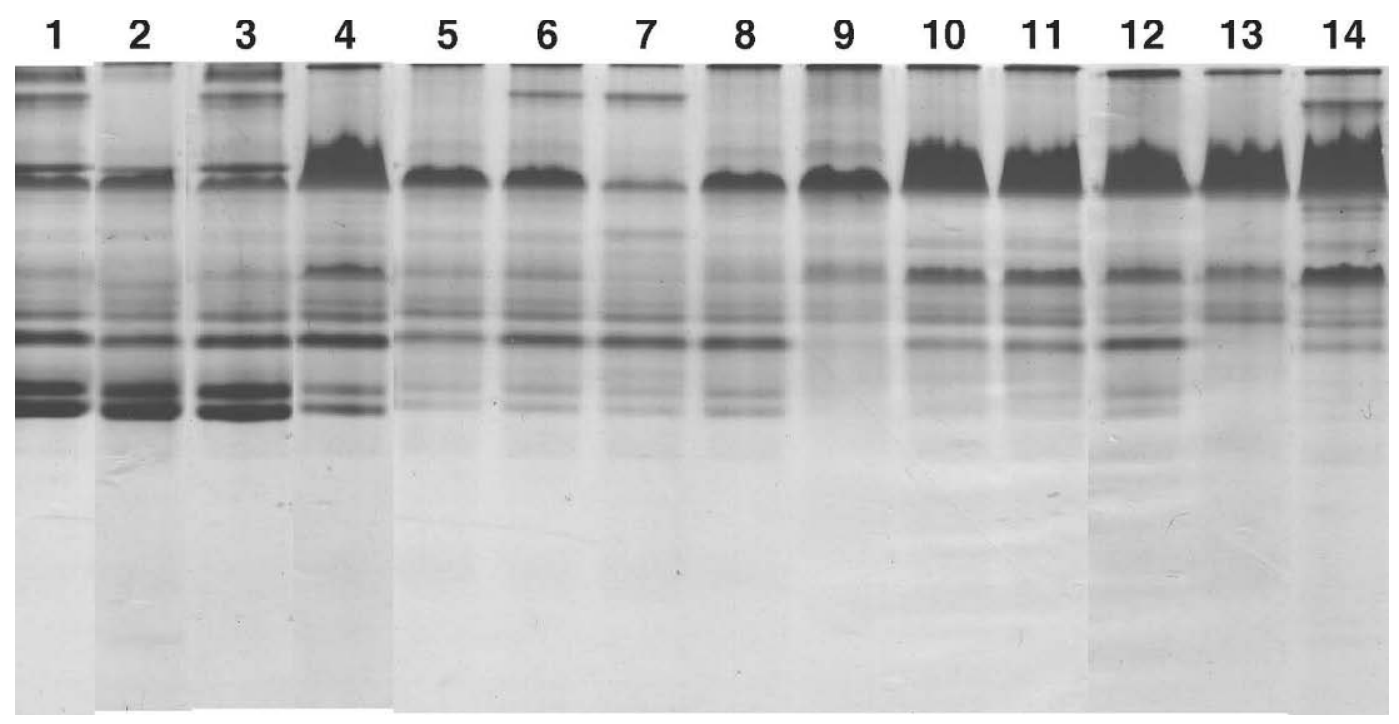

Figure 7. Characterization of $\beta$-LG content in processed milk using native PAGE. Whey protein of skimmed milk (n = 14; $10 \mu \mathrm{g}$ each) was loaded on a $15 \%$ native PAGE and stained by Coomassie blue. For the preparation of whey protein, milk samples were immediately centrifuged at $13,000 \mathrm{rpm}(15,500 \times \mathrm{g})$ for $1 \mathrm{~h}$ at $4^{\circ} \mathrm{C}$. The top layer in the supernatant was carefully removed, and the remaining fraction (whey protein) containing minimal casein was used for the analysis. Lane 1: raw milk; lane 2: processed milk from a local market pasteurized at $60^{\circ} \mathrm{C}$ for $30 \mathrm{~min}$; lane 3: processed milk from a US market pasteurized with a standard procedure; lanes 4 to 14: processed milk of various brands from a local market with undisclosed heating procedures. $\beta$-Lactoglobulin concentration in each milk was determined by native mAb using an ELISA. The designated sample number of each tested milk was the same as that shown in Table $1(\mathrm{n}=14)$.

$40^{\circ} \mathrm{C}$. The next morning, the mixture is cooled to $30^{\circ} \mathrm{C}$, inoculated with a lactic acid culture, and incubated for $30 \mathrm{~min}$. Rennet extract is added, and the mixture is stirred, resulting in coagulation of curd (Marshall, 2004). According to our curve for thermal denaturation constructed by the mAb (Figure 4), $\beta$-LG is likely intact using these standard procedures. The present study shows the use of native $\mathrm{mAb}$ in determining the native $\beta$-LG concentration in processed milk (Table 1), but not of the polyclonal antibodies, as they recognized both native and denatured $\beta$-LG (Chen et al., 2005). Table 1 illustrates that the $\beta$-LG content varied significantly among the brands we tested. Although the status for the manufactured process is not disclosed and is not yet readily known, our study indicates the remarkable difference among the procedures for thermal sterilization and pasteurization as previously indicated (Douglas et al., 1981). Therefore, it is recommended that the heating process should be eventually standardized to avoid unnecessary overheating by our domestic manufacturers. In conclusion, the present study provides evidence that a novel conformation-dependent $\beta$-LG mAb can be prepared via an appropriate immunization strategy and screening. Such native mAb can be used as a unique reagent to routinely monitor the quality of dairy products when $\beta$-LG is considered to be an essential ingredient.

\section{ACKNOWLEDGMENT}

This work was supported by grants 90-2313-B-009001, 91-2313-B-009-001, 92-2313-B-009-002, 93-2313B-009-002, and 94-2313-B-009-001 from the National Science Council, Taiwan, Republic of China.

\section{REFERENCES}

Andrews, P. C., M. M. Allen, M. L. Vestal, and R. W. Nelson. 1992. Large scale protein mapping using infrequent cleavage reagents, LD TOF MS, and ES MS. Pages 515-523 in Techniques in Protein Chemistry II. R. M. Angeletti, ed. Academic Press, San Diego, CA.

Beavis, R. C., and B. T. Chait. 1990. Rapid, sensitive analysis of protein mixtures by mass spectrometry. Proc. Natl. Acad. Sci. USA 87:6873-6877.

Braunschweig, M., C. Hagger, G. Stranzinger, and Z. Puhan. 2000. Associations between casein haplotypes and milk production traits of Swiss brown cattle. J. Dairy Sci. 83:1387-1395.

Caprioli, R. M., B. Whaley, K. K. Mock, and J. S. Cottrell. 1991. Sequence-ordered peptide mapping by time-course analysis of protease digests using laser description mass spectrometry. Pages 497-510 in Techniques in Protein Chemistry II. R. M. Angeletti, ed. Academic Press, San Diego, CA.

Chang, J. Y., A. Bulychev, and L. Li. 2000. A stabilized molten globule protein. FEBS Lett. 487:298-300.

Chen, W. L., M. T. Hwang, C. Y. Liau, J. C. Ho, K. C. Hong, and S. J. T. Mao. 2005. Beta-lactoglobulin is a thermal marker in processed milk as studied by electrophoresis and circular dichroic spectra. J. Dairy Sci. 88:1618-1630.

Chen, W. L., M. T. Hwang, H. C. Liu, C. W. Li, and S. J. T. Mao. 2004. Distinction between dry and raw milk using monoclonal antibodies prepared against dry milk proteins. J. Dairy Sci. 87:2720-2729. 
Creamer, L. K., A. Bienvenue, H. Nilsson, M. Paulsson, M. van Wanroij, E. K. Lowe, S. G. Anema, M. J. Boland, and R. JimenezFlores. 2004. Heat-induced redistribution of disulfide bonds in milk proteins. 1. Bovine beta-lactoglobulin. J. Agric. Food Chem. $52: 7660-7668$.

Croguennec, T., D. Molle, R. Mehra, and S. Bouhallab. 2004. Spectroscopic characterization of heat-induced nonnative beta-lactoglobulin monomers. Protein Sci. 13:1340-1346.

de Jongh, H. H. J., T. Gröneveld, and J. de Groot. 2001. Mild isolation procedure discloses new protein structural properties of $\beta$-lactoglobulin. J. Dairy Sci. 84:562-571.

Dew, S. E., and D. E. Ong. 1997. Absorption of retinol from the retinol:retinol-binding protein complex by small intestinal gut sheets from the rat. Arch. Biochem. Biophys. 338:233-236.

Douglas, F. W., Jr., R. Greenberg, H. M. Farrell, Jr., and L. F. Edmondson. 1981. Effects of ultra-high-temperature pasteurization on milk proteins. J. Agric. Food Chem. 29:11-15.

Farrell, H. M., R. Jimenez-Flores, G. T. Bleck, E. M. Brown, J. E. Butler, L. K. Creamer, C. L. Hicks, C. M. Hollar, K. F. Ng-KwaiHang, and H. E. Swaisgood. 2004. Nomenclature of the proteins of cows' milk-Sixth revision. J. Dairy Sci. 87:1641-1674.

Feuermann, Y., S. J. Mabjeesh, and A. Shamay. 2004. Leptin affects prolactin action on milk protein and fat synthesis in the bovine mammary gland. J. Dairy Sci. 87:2941-2946.

Forge, V., M. Hoshino, K. Kuwata, M. Arai, K. Kuwajima, C. A. Batt, and Y. Goto. 2000. Is folding of beta-lactoglobulin non-hierarchic? Intermediate with native-like beta-sheet and non-native alphahelix. J. Mol. Biol. 296:1039-1051.

Hernandez-Ledesma, B., A. Davalos, B. Bartolome, and L. Amigo. 2005. Preparation of antioxidant enzymatic hydrolysates from alpha-lactalbumin and beta-lactoglobulin. Identification of active peptides by HPLC-MS/MS. J. Agric. Food Chem. 53:588-593.

Kontopidis, G., C. Holt, and L. Sawyer. 2002. The ligand-binding site of bovine beta-lactoglobulin: Evidence for a function? J. Mol. Biol. 318:1043-1055.

Kontopidis, G., C. Holt, and L. Sawyer. 2004. Invited review: Betalactoglobulin: Binding properties, structure, and function. J. Dairy Sci. 87:785-796

Mao, S. J. T., R. E. Kazmar, J. C. Silverfield, M. C. Alley, K. Kluge, and C. G. Fathman. 1982. Immunochemical properties of human low density lipoproteins as explored by monoclonal antibodies. Binding characteristics distinct from those of conventional serum antibodies. Biochim. Biophys. Acta 713:365-374.

Mao, S. J. T., J. G. Patton, J. J. Badimon, B. A. Kottke, M. C. Alley, and A. D. Cardin. 1983. Monoclonal antibodies to human plasma low-density lipoproteins. I. Enhanced binding of 125I-labeled lowdensity lipoproteins by combined use of two monoclonal antibodies. Clin. Chem. 29:1890-1897.

Mao, S. J. T., A. E. Rechtin, and R. L. Jackson. 1988. Monoclonal antibodies that distinguish between active and inactive forms of human postheparin plasma hepatic triglyceride lipase. J. Lipid Res. 29:1023-1029.

Mao, S. J. T., A. E. Rechtin, J. L. Krstenansky, and R. L. Jackson. 1990. Characterization of a monoclonal antibody specific to the amino terminus of the alpha-chain of human fibrin. Thromb. Haemost. 63:445-448.

Mao, S. J. T., J. T. Sparrow, E. B. Gilliam, A. M. Gotto, and R. L. Jackson. 1977. Mechanism of lipid-protein interaction in the plasma lipoproteins: Lipid-binding properties of synthetic fragments of apolipoprotein A-II. Biochemistry 16:4150-4156.

Mao, S. J. T., J. T. Sparrow, A. M. Gotto, and R. L. Jackson. 1980. The phospholipid-binding and immunochemical properties of amidinated, guanidinated and acetylated apolipoprotein A-II. Biochim. Biophys. Acta 617:245-253.

Marshall, K. 2004. Therapeutic applications of whey protein. Altern. Med. Rev. 9:136-156.
Morrison, J. R., N. H. Fidge, and B. Grego. 1990. Studies on the formation, separation, and characterization of cyanogen bromide fragments of human AI apolipoprotein. Anal. Biochem. 186:145-152.

Nagaoka, S., F. Yu, M. Keiji, A. Takako, Y. Kouhei, K. Yoshihiro, T. Kojima, and K. Tamotsu. 2001. Identification of novel hypocholesterolemic peptides derived from bovine milk $\beta$-lactoglobulin. Biochem. Biophys. Res. Commun. 281:11-17.

Needs, E. C., M. Capellas, A. P. Bland, P. Manoj, D. MacDougal, and G. Paul. 2000. Comparison of heat and pressure treatments of skim milk, fortified with whey protein concentrate, for set yogurt preparation: Effects on milk proteins and gel structure. J. Dairy Res. 67:329-348.

Oldfield, D. J., H. Singh, M. W. Taylor, and K. N. Pearce. 1998. Kinetics of denaturation and aggregation of whey protein in skim milk heated in an ultra-high temperature (UHT) plant. Int. Dairy J. 8:311-318.

Panick, G., R. Malessa, and R. Winter. 1999. Differences between the pressure- and temperature-induced denaturation and aggregation of beta-lactoglobulin A, B, and AB monitored by FT-IR spectroscopy and small-angle X-ray scattering. Biochemistry 38:6512-6519.

Patton, J. G., J. J. Badimon, and S. J. T. Mao. 1983. Monoclonal antibodies to human plasma low-density lipoproteins. II. Evaluation for use in radioimmunoassay for apolipoprotein $\mathrm{B}$ in patients with coronary artery disease. Clin. Chem. 29:1898-1903.

Peña-Ramos, E. A., and Y. L. Xiong. 2001. Antioxidative activity of whey protein hydrolysates in a liposomal system. J. Dairy Sci. 84:2577-2583.

Pérez, M. D., and M. Calvo. 1995. Interaction of $\beta$-lactoglobulin with retinol and fatty acids and its role as a possible biological function for this protein: A review. J. Dairy Sci. 78:978-988.

Qin, B. Y., M. C. Bewley, L. K. Creamer, H. M. Baker, E. N. Baker, and G. B. Jameson. 1998. Structural basis of the Tanford transition of bovine beta-lactoglobulin. Biochemistry 37:14014-14023.

Qin, B. Y., M. C. Bewley, L. K. Creamer, E. N. Baker, and G. B. Jameson. 1999. Functional implications of structural differences between variants A and B of bovine beta-lactoglobulin. Protein Sci. 8:75-83.

Sava, N., I. Van der Plancken, W. Claeys, and M. Hendrickx. 2005. The kinetics of heat-induced structural changes of $\beta$-lactoglobulin J. Dairy Sci. 88:1646-1653.

Song, C. Y., W. L. Chen, M. C. Yang, J. P. Huang, and S. J. T. Mao. 2005. Epitope mapping of a monoclonal antibody specific to bovine dry milk: Involvement of residues 66-76 of strand D in thermal denatured beta-lactoglobulin. J. Biol. Chem. 280:3574-3582.

Tseng, C. F., C. C. Lin, H. Y. Huang, H. C. Liu, and S. J. T. Mao. 2004. Antioxidant role of human haptoglobin. Proteomics 4:2221-2228.

Uhrinova, S., M. H. Smith, G. B. Jameson, D. Uhrin, L. Sawyer, and P. N. Barlow. 2000. Structural changes accompanying pHinduced dissociation of the beta-lactoglobulin dimer. Biochemistry 39:3565-3574.

Wang, T., and J. A. Lucey. 2003. Use of multi-angle laser light scattering and size-exclusion chromatography to characterize the molecular weight and types of aggregates present in commercial whey protein products. J. Dairy Sci. 86:3090-3101.

Wong, P. Y. Y., and D. D. Kitts. 2003. Chemistry of buttermilk solid antioxidant activity. J. Dairy Sci. 86:1541-1547.

Wu, S. Y., M. D. Perez, P. Puyol, and L. Sawyer. 1999. Beta-lactoglobulin binds palmitate within its central cavity. J. Biol. Chem. 274:170-174.

Yang, J., A. K. Dunker, J. R. Powers, S. Clark, and B. G. Swanson. 2001. Beta-lactoglobulin molten globule induced by high pressure. J. Agric. Food Chem. 49:3236-3243.

Yang, S. J., and S. J. T. Mao. 1999. A simple HPLC purification procedure for porcine plasma haptoglobin. J. Chromatagr. B 731:395-402. 